\title{
The Importance of Assessing Quality of Life in Patients with Alcohol Dependence
}

\author{
Zrnka Kovačić Petrović ${ }^{1 *}$, Tina Peraica ${ }^{2,3^{*}}$, Dragica Kozarić-Kovačić3 \\ ${ }^{1}$ University of Zagreb, School of Medicine, University Psychiatric Hospital Vrapče, Zagreb, \\ Croatia, ${ }^{2}$ University Hospital Dubrava, Department of Psychiatry, Referral Center for \\ Stress-related Disorders of the Ministry of Health, Zagreb, Croatia, ${ }^{3}$ University Depart- \\ ment for Forensic Sciences, University of Split, Split, Croatia *Zrnka Kovačić Petrović and \\ Tina Peraica contributed equally to the study.
}

\begin{abstract}
Alcohol dependence has a strong impact on quality of life ( $Q \circ L)$ and $\mathrm{OoL}$ assessment is considered as a valid measure in evaluating the success of the treatment of patients with alcohol dependence. The goal of the study was to investigate QoL and some sociodemographic characteristics of patients with alcohol dependence in comparison with healthy individuals. Cross-sectional study (which is part of larger study) included 312 patients with alcohol dependence and 329 healthy individuals of both sexes. Structured interview for sociodemographic and alcohol related data, the Croatian version of the 5.00 Mini International Neuropsychiatric Interview (MINI), and the short version of the World Health Organization Quality of Life (WHOQoLBREF) were used. The results have shown that alcohol dependent patients were significantly more frequently uneducated $(p=0.006)$ and primary education $(p<0.001)$, while healthy individuals were significantly more likely to have secondary $(p=0.003)$ and tertiary education $(p=0.013)$. Patients with alcohol dependence were significantly more likely to be single $(p=0.005)$, divorced $(p<0.001)$, and living as married $(p=0.008)$ compared to healthy people, while healthy populations were more often married $(p<0.001)$ in comparison to alcohol addicts. Alcohol dependent persons were more often unemployed $(p<0.001)$ and retired $(p=0.005)$. Patients with alcohol dependence were more likely to have a perceived a sense of illness $(p<0.001)$ than healthy subjects. There were significant differences in all domains of QoL: general, physical, psychological, social, and environment between patients with dependence and healthy individuals $(p<0.001)$. To conclude, alcohol dependence has been shown to be negatively correlated with overall QoL and domains of QoL: physical, psychological, social, and environmental. Education of patients with alcohol dependence was lower than in healthy people, who were more likely to live in marriage and were employed.
\end{abstract}

Key words: alcohol dependence, quality of life, assessment

Copyright @ 2021 KBCSM, Zagreb

e-mail: alcoholism.kbcsm@gmail.com•www.http://apr.kbcsm.hr

Correspondence to:

Zrnka Kovačić Petrović, MD, PhD

University Psychiatric Hospital Vrapče,

Bolnička cesta 32, 10000 Zagreb, Croatia

Phone: +38598230969

E-mail: zrnka.kovacic@gmail.com

\section{Introduction}

The last forty years have seen a growing interest in assessing the quality of life (QoL) in clinical practice and research related to health and diseases [1]. QoL measurements have be- 
come an increasingly established method in assessing outcomes in clinical practice and in clinical trials related to health and disease and QoL has become a key outcome measure for health care assessment in chronic disorders such as malignant disorders, connective tissue disorders, cardiovascular disease, and some mental illness [2,3]. QoL self-reported measures have shown adequate validity and reliability in mental health evaluations and in treatments of many disorders, including alcohol use disorder (AUD), e.g. (alcohol abuse and dependence) $[2,4]$.

Measurements of QoL can be clinically useful in motivating patients to continue in treatment and to overcome difficulties with their alcohol abuse and dependence because an impaired QoL is the primary motivation for seeking help and treatment [5].

AUD are one of the major health problems in the world, as well as in Croatia [6]. A disease is very often refractory to treatment with chronic course associated with high mental and physical comorbidities. AUD severely affect patients and their families with strong impact on their functioning. Research in Croatia showed that $6 \%$ of adult men were alcohol dependent, 15\% were moderate consumers [7] and 10 to $20 \%$ of psychiatric beds in Croatia are occupied by alcohol dependent patients [8]. According to the World Health Organization, Croatia was ranked fourth in the list of countries by alcohol consumption in 2014 [6]. In the $1995-2005$ period, Croatia was the only country in which the drinking prevalence increased by more than $10 \%$, as shown by the European School Survey Project on Alcohol and Other Drugs (ESPAD) [9].

Although some authors consider QoL assessment to be a significant factor in evaluating treatment outcomes in people with AUD
$[10,11]$, it is still less commonly used than other measure treatment outcomes such as: problems with the law, employment, hospitalization rates, abstinence days, mortality and morbidity [12].

Because alcohol disorders have a strong impact on QoL, one of the goals of the study (only one part of the study is shown here) was to investigate the QoL and some sociodemographic characteristics (age, education, marital status, and employment) of patients with alcohol dependence in relation to healthy population.

\section{Participants and methods}

\section{Participants}

The study was conducted at the Department for Alcoholism, University Psychiatric Hospital Vrapče, Zagreb, from January 2015 to December 2016. It included 312 patients with alcohol dependence, aged 18-60 years, consecutively admitted for detoxification and alcoholism treatment. They were age over 18 years, meeting the criteria for current alcohol dependence according to the Diagnostic and Statistical Manual of Mental Disorders, $4^{\text {th }}$ edition - text revision (DSM-IV-TR) and the International Classification of Diseases, $10^{\text {th }}$ revision (ICD-10) [13,14]. Structured interviews were used to collect socio-demographic and alcohol-related data [15]. The Croatian version 5.0.0 of MINI [16] was used to evaluate psychiatric morbidity in all participants.

The research was done between the $10^{\text {th }}$ and $15^{\text {th }}$ day after admission to increase the validity and reliability of the collected data. Upon admission, they received psychopharmacological therapy for detoxification and removal of withdrawal symptoms. Inclusion criteria were as follows: alcohol consumption 
in the past six months, no organic difficulties or schizophrenia or affective disorder of non-alcoholic etiology, no other primary causes of impaired intelligence, and endured hospitalization for at least 15 days after admission. Eligible participants were invited to participate in the study. Their decision whether to participate or not had no effect on the treatment they received.

Healthy individuals were recruited as controls from the population undergoing regular systematic physical examination at the University Hospital Dubrava in Zagreb. They were assessed by the Croatian version 5.0.0 of the Mini International Neuropsychiatric Interview (MINI) to exclude psychiatric disorders [16]. Twenty-three women were excluded because of alcoholism, anxiety, and depressive psychopathology and 28 men were excluded because of alcoholism, depressive and anxiety disorders.

\section{Methods}

The following measurement instruments were used: a structured interview for general data collection, including age, education, employment, and marital status, the Croatian version 5.0.0 of the Mini International Neuropsychiatric Interview (MINI), and the World Health Organization Quality of Life-Bref (WHOQoL-BREF), developed as an international, cross-culturally comparable QoL assessment instrument [15-18]. WHOQoL-BREF is the most frequently used, person-centered self-report instrument for the subjective assessment of QoL [18], which measures general QoL and four domains of QoL: physical health, psychological health, social relations, and environment. It has good psychometric characteristics [18]. It consists of 24 items measuring the four
QoL domains, specifically physical health (7 items: activities of daily living, dependence on medical substances and medical aids, energy and fatigue, mobility, pain and discomfort, sleep and rest, work capacity), psychological health (6 items: bodily image and appearance, negative feelings, positive feelings, self-esteem, spirituality/religion/personal beliefs, thinking, learning, memory and concentration), social relationships (3 items: personal relationship, social support, sexual activity), and environment (8 items: financial resources, freedom, physical safety and security, accessibility and quality of health care, home environment, opportunities for acquiring new information and skills, participation in an opportunities for recreation/leisure activities, physical environment). Furthermore, it has 26 items that separately measure two domains: the person's overall perception of QoL (overall QoL) (range: 1-5, with 1 being "very poor", and 5 being "very good") and general perception of health (general health) (range: 1-5, with 1 being "very unsatisfied", and 5 being "very satisfied"). Higher scores indicate better QoL. The level of satisfaction or degree of agreement for each item is rated on a 5-point Likert scale. The score for each domain is defined as the sum of individual item scores on subscales transformed into a scale from 0 to 100 (higher scores indicating better QoL).

The Cronbach's alpha coefficients were: for physical health $(\alpha=0.874)$, psychological health $(\alpha=0.866)$, social relationships $(\alpha=0.6729)$ and environment $(\alpha=0.787)$, and the total for 26 items $(\alpha=0.942)$. These coefficients were higher than the ones reported previously by WHOQoL Group for Croatian sample [18].

The Ethics Committees of the University Psychiatric Hospital Vrapče and the Univer- 
sity Hospital Dubrava approved the study. All participants gave their written informed consent.

\section{Statistical analysis}

The normality of distribution for continuous variables was tested with KolmogorovSmirnov and Shapiro-Wilks tests separately for each group. Non-parametric tests for comparison between groups were used for variables that did not show normal distribution. Mann-Whitney $U$ test was used to determine differences among the group of $\mathrm{pa}$ tients with alcohol dependence and group of healthy persons. Pearson's $\chi^{2}$ test was used to compare two categorical variables. $P$ values at $\mathrm{p}<0.01$ were considered statistically significant.

All statistical analyses were performed using a free software environment $\mathrm{R}$, version 3.3.2 and open source statistical software RStudio, version 1.0.136 [19,20]. When calculating differences between groups, the effect size was calculated for each analysis [21].

\section{Results}

\section{Sociodemographic characteristics}

The groups differ significantly in age (U $=28019.0, \mathrm{p}=0.001, \mathrm{r}=0.15)$. The healthy subjects were slightly younger (Median $=47$ ) than the alcohol dependent persons (Median $=51)$. Statistically significant differences were obtained between patients with alcohol dependence and healthy persons in education $(\chi 2(3)=55.165, \mathrm{p}<0.001$, Cramer's $\mathrm{V}=0.321)$, marital status $(\chi 2(4)=93.298$, $\mathrm{p}<0.001$, Cramer's $\mathrm{V}=0.419)$, employment, $(\chi 2(2)=57.234, \mathrm{p}<0.001$, Cramer's V $=0.489)$, and perception of illness $\left(\chi^{2}(1)=\right.$ 187.593, $\mathrm{p}<0.001, \mathrm{f}=0.592)$.
Alcohol dependent persons were more often uneducated $(\mathrm{p}=0.006)$ and primary education ( $p<0.001)$, while healthy individuals were more likely to have secondary ( $\mathrm{p}=$ $0.003)$ and tertiary education $(p=0.013)$.

Alcohol addicts were more likely to be single $(p=0.005)$, divorced $(p<0.001)$, and living as married $(p=0.008)$ in relation to healthy individuals, while healthy subjects were more likely to be married ( $p<0.001$ ). Alcohol dependent people and healthy individuals were equally frequent widowers ( $p$ $=0.313$ ). Patients with alcohol dependence were more often unemployed $(p<0.001)$ and retired $(p=0.005)$, while healthy subjects were more likely to be employed ( $p<0.001)$. Alcohol dependent persons were more likely to have a sense of illness $(p<0.001)$ than healthy subjects (Table 1$)$.

\section{Comparisons of patients with alcohol dependence and healthy individuals in quality of life domains}

Significant differences in overall QoL (U $=49348.0, \mathrm{p}<0.001, \mathrm{r}=0.42)$ were found between alcohol dependent persons and healthy individuals. Patients with alcohol dependence (Median = 3) had a slightly lower overall QoL than healthy individuals (Median $=4)$. There were statistically significant differences in health status $(\mathrm{U}=53387.0, \mathrm{p}$ $<0.001, \mathrm{r}=0.51)$ between patients with alcohol dependence and healthy individuals. Patients with alcohol dependence had slightly lower health status (Median = 3) than healthy individuals (Median = 4). Physical QoL also showed significant differences between groups $(\mathrm{U}=55727.0, \mathrm{p}<0.001, \mathrm{r}$ $=0.54)$. Persons addicted on alcohol had a lower physical QoL (Median = 61) than healthy subjects (Median = 86). Statistically significant differences in psychological QoL 
Table 1. Participants' characteristics and comparison of scores across QoL domains

\begin{tabular}{|c|c|c|c|c|}
\hline & \multicolumn{2}{|c|}{ No. $(\%)$ of participants } & \multirow[b]{2}{*}{ test } & \multirow[b]{2}{*}{$\mathrm{p}$} \\
\hline & $\begin{array}{l}\text { Alcoholics } \\
(\mathrm{n}=312)\end{array}$ & $\begin{array}{l}\text { Non-alcoholics } \\
\quad(\mathrm{n}=329)\end{array}$ & & \\
\hline $\begin{array}{l}\text { Age (median, Q1-Q3; } \\
\text { years) }\end{array}$ & $51(43-56)$ & $47(41-54)$ & $\mathrm{U}=28019.0^{*}$ & 0.001 \\
\hline Education level; f (\%) & & & $\chi^{2(3)}=55.165^{* *}$ & $<0.001$ \\
\hline none & $12(3.9)$ & $2(0.6)$ & & \\
\hline primary & $71(22.7)$ & $13(4.0)$ & & \\
\hline secondary & $176(56.5)$ & $228(69.3)$ & & \\
\hline tertiary & $53(16.9)$ & $86(26.1)$ & & \\
\hline Marital status; $f(\%)$ & & & $\chi^{2}(4)=93.298^{* *}$ & $<0.001$ \\
\hline single & $92(29.5)$ & $63(19.1)$ & & \\
\hline married & $113(36.2)$ & $241(73.2)$ & & \\
\hline divorced & $71(22.7)$ & $8(2.5)$ & & \\
\hline living as married & $21(6.8)$ & $7(2.2)$ & & \\
\hline widowed & $15(4.8)$ & $10(3.1)$ & & \\
\hline Employment; $f(\%)$ & & & $\chi^{2}(2)=57.234^{* *}$ & $<0.001$ \\
\hline employed & $113(36.2)$ & $296(89.9)$ & & \\
\hline unemployed & $108(34.9)$ & $11(3.3)$ & & \\
\hline retired & $91(29.2)$ & $22(6.7)$ & & \\
\hline Currently ill; $f(\%)$ & $207(66.2)$ & $32(9.7)$ & $\chi^{2(1)}=187.593^{* *}$ & $<0.001$ \\
\hline \multicolumn{5}{|l|}{$\begin{array}{l}\text { WHOQoL-BREF scores } \\
\text { (median, Q1-Q3) }\end{array}$} \\
\hline overall QoL & $3(3-4)$ & $4(4-4)$ & $\mathrm{U}=49348.0^{* *}$ & $<0.001$ \\
\hline general health & $3(2-4)$ & $4(4-5)$ & $\mathrm{U}=53387.0^{* *}$ & $<0.001$ \\
\hline physical health & $61(46-75)$ & $86(75-93)$ & $\mathrm{U}=55727.0^{* *}$ & $<0.001$ \\
\hline psychological health & $58(46-71)$ & $79(71-92)$ & $\mathrm{U}=54258.0^{* *}$ & $<0.001$ \\
\hline social relations & $67(50-75)$ & $75(75-92)$ & $\mathrm{U}=52077.0^{* *}$ & $<0.001$ \\
\hline environmental & $63(47-75)$ & $72(66-81)$ & $\mathrm{U}=46446.5^{* *}$ & $<0.001$ \\
\hline
\end{tabular}

QoL - quality of life; Q1-Q3 - interquartile range; WHOQoL-BREF - The World Health Organization Quality of Life Questionnaire, short form

Legend: Alcoholics $=$ Patients with alcohol dependence; Non-alcoholics $=$ Healthy controls $\mathrm{p}<.01 * ; \mathrm{p}<.001^{* *}$

between groups were obtained $(\mathrm{U}=54258.0$, dependence had a lower psychological QoL $\mathrm{p}<0.001, \mathrm{r}=0.50)$. Patients with alcohol (Median $=58)$ than healthy individuals (Me- 
dian $=79)$. Social QoL showed a significant difference between alcohol dependent and healthy persons $(\mathrm{U}=52077.0, \mathrm{p}<0.001, \mathrm{r}=$ 0.46). Alcohol addicts had a lower social QoL (Median = 67) compared to healthy individuals $($ Median $=75)$. Significant differences in QoL were also found with respect to the environment between alcohol dependent and healthy individuals $(\mathrm{U}=46446.5, \mathrm{p}<0.001$, $\mathrm{r}$ $=0.31$ ). Persons dependent on alcohol had a lower QoL in environment domain (Median =63) than healthy individuals (Median = 72).

\section{Discussion}

The results of this study showed that patients with alcohol dependence had a lower overall QoL, as well as a lower score in all domains of QoL (physical, psychological, social, and environment) compared to healthy controls. These results are consistent with other studies $[3,22]$. In the cross-sectional study that examined primary care patients with alcohol dependence and alcohol abuse significant differences were found in QoL between the healthy patients and the alcohol dependent group measured by the Medical Outcomes Study Short Form (SF-36) [22]. No significant differences were found in QoL between alcohol abuse and healthy groups [22]. Limitations of this study is no differentiation between problems due to alcohol consumption and other problems and as the study was cross-sectional, cannot determined causality. In addition, two studies showed lower scores on psychological functioning and role obligations in inpatients and outpatients with alcohol dependence [23,24].

There are various measuring instruments for assessing the QoL. In this study we applied WHOQoL-BREF because it might have a slight advantage in measuring QoL in persons with alcohol abuse and dependence [3]. This scale provides comparison of QoL across various disorders and has good reliability measures [25,26], although is not disorder-specific [27].

There were also significant differences in some sociodemographic characteristics (education, marital status, and employment) between patients with alcohol dependence and healthy individuals. Many sociodemographic factors have been found to influence QoL of alcoholics, including older age [24,28], female sex [3,24,28,29], lower education level [30], low socioeconomic status [31], single status [31], living alone [24], and inpatient treatment [24].

In our study overall QoL, as well as domains of QoL (physical, psychological, social, and environment) have been shown to be negatively associated with alcohol dependence. Education, marital status, and employment have also proved negative association with alcohol dependence. This is consistent with the data that individuals with higher socioeconomic status may consume equal or similar amounts of alcohol compared to persons with lower socioeconomic status, which have more severe negative effects caused by alcohol [32].

The limitations of the study are that it was designed as a cross-sectional study, which precludes causal inference, and that we did not investigate the impact of psychiatric and somatic comorbidity on QoL. It is doubtful that our results are comparable with other studies that used different QoL measurement instruments. However, our study samples were large enough to allow us to detect the differences between patients with alcohol dependence and healthy controls. The data for patients with alcohol dependence were collected from inpatients with standardized 
measurement instruments by a experienced psychiatrist in the field of alcohology and the data on healthy controls were collected by experienced professionals.

In conclusion, QoL is significantly impaired in alcohol dependence. Therefore, QoL assessment should also be used during the evaluation of the effectiveness of treatment of patients with alcohol dependence. In addition to clinical evaluation, it would be useful to apply self-assessment QoL instruments that have shown good validity and reliability in mental health assessment and treatment of many disorders, including alcohol

\section{References}

1. World Health Organization, Division of Mental Health and Prevention of Substance Abuse. WHOQoL: measuring quality of life [Internet]. 1997 [Cited January $\left.5^{\text {th }} 2020\right]$. Available from: https://www.who.int/mental_health/media/68. pdf

2. Murray CJL, Lopez AD. The global burden of disease: a comprehensive assessment of mortality and disability from disease, injuries, and risk factors in 1990 and projected to 2020. Cambridge, USA: Harvard University Press; 1996.

3. Ugochukwu C, Bagot KS, Delaloye S, Pi S, Vien L, Garvey T, et al. The importance of quality of life in patients with alcohol abuse and dependence. Harv Rev Psychiatry. 2013;21:1-17.

4. IsHak WW, Greenberg JM, Balayan K, Kapitanski N, Jeffrey J, Fathy K. et al. Quality of life: the ultimate outcome measure of interventions in major depressive disorder. Harv Rev Psychiatry. 2011;19:229-39.

5. Laudet AB, Becker JB, White WL. Don't wanna go through that madness no more: quality of life satisfaction as predictor of sustained remission from illicit drug misuse. Subst Use Misuse. 2009;44:22752. abuse /dependence [3]. In alcohol use disorders this could help in motivating patients for treatment because they very often negate or decrease the dependence on alcohol and its consequences, as shown by this survey, since only 66.2 percent of patients with alcohol dependence reported being currently ill.

\section{Acknowledgements}

None.

\section{Conflicts of interest}

None to declare.

6. World Health Organization. Global status report on alcohol and health [Internet]. 2014 [Cited January $5^{\text {th }}$ 2020]. Available from: https://www.who. int/substance_abuse/publications/alcohol_2014/ en/

7. Institute of Social Sciences Ivo Pilar. Substance abuse in general population in the Republic of Croatia - research report [Internet]. 2012 [Cited January $5^{\text {th }}$ 2020]. Available from: https://www. pilar.hr/wp-content/images/stories/dokumenti/ elaborati/substance_abuse_among.pdf

8. Stevanović R, Capak K, Benjak T. Croatian health statistics yearbook 2015 - web edition. Zagreb: Croatian Institute of Public Health; 2016. p. 289.

9. ESPAD. Results from the European School Survey Project on Alcohol and Other Drugs [Internet]. 2016 [Cited January $5^{\text {th }}$ 2020]. Available from: http:/ / www.emcdda.europa.eu/publications / joint-publications/emcdda-espad-report_en

10. Donovan D, Mattson ME, Cisler RA, Longabaugh $\mathrm{R}$, Zweben A. Quality of life as outcome measure in alcoholism treatment research. J Stud Alcohol Suppl. 2005;15:119-39.

11. Levola J, Aalto M, Holopainen A, Cieza A, Pitkanen T. Health-related quality of life in alcohol dependence: A systematic literature review with 
specific focus on the role of depression and other psychopathology. Nord J Psychiatry. 2014;68:36984.

12. Finney JW, Moyer A, Swearingen CE. Outcome variables and their assessment in alcohol treatment studies: 1968-1998. Alcohol Clin Exp Res. 2003;27:1671-9.

13. American Psychiatric Association. Diagnostic and statistical manual of mental disorders, 4th ed., Text Revision (DSM-IV-TR). Washington, USA: American Psychiatric Association; 2000.

14. World Health Organization. International Statistical Classification of Diseases and related Health Problems, 10th revision. Geneva, CH: World Health Organization; 1992.

15. Kovačić Petrović Z, Peraica T, Kozarić-Kovačić D. Comparison of ego strength between aggressive and non-aggressive alcoholics: a cross-sectional study. Croat Med J. 2018;59:156-64.

16. Sheehan DV, Lecrubier Y, Sheehan KH, Amorim P, Janavs J, Weiller E, et al. The Mini International Neuropsychiatric Interview (M.I.N.I.): the development and validation of a structured diagnostic psychiatric interview. J Clin Psychiatry. 1998;59:2233.

17. World Health Organization. WHOQOL-BREF: Introduction, administration, scoring, and generic version of the assessment [Internet]. 1996 [Cited January $5^{\text {th] }}$ 2020]. Available from: https://www. who.int/mental_health/media/en/76.pdf

18. Skevington SM, Lotfy M, O'Conell KA. The World Health Organization WHOQOL-BREF quality of life assessment: psychometric properties and results of the international field trail. A report from the WHOQOL group. Qual Life Res. 2004;13:299-310.

19. R Core Team. R: A Language and Environment for Statistical Computing [Internet] 2017 [Cited January $\left.5^{\text {thl }} 2020\right]$. Available from:https://www.rproject.org

20. R Studio Team. RStudio: Integrated Development for R (Version 1.0.136) [Internet]. 2017 [Cited Jan-

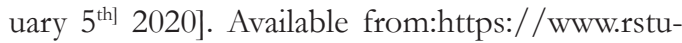
dio.com

21. Cohen J. Statistical Power Analysis for the Behavioral Sciences (2nd ed.). Hillsdale, USA: Lawrence Erlbaum Associates, Publishers; 1988.
22. Volk RJ, Cantor SB, Steinbauer JR, Cass AR. Alcohol use disorders, consumption patterns, and health-related quality of life of primary care patients. Alcohol Clin Exp Res. 1997;21:899-905.

23. Daeppen JB, Krieg MA, Burnand B, Yersin B. MOS-SF-36 in evaluating health-related quality of life in alcohol-dependent patients. Am J Drug Alcohol Abuse. 1998;24:685-94.

24. Malet L, Llorca PM, Beringuier B, Lehert P, Falissard B. AlQoL 9 measuring quality of life in alcohol dependence. Alcohol Alcohol. 2006;41:181-7.

25. Peraica T, Vidović A, Kovačić Petrović Z, KozarićKovačić D. Quality of life of Croatian veterans' wives and veterans with posttraumatic stress disorder. Health Qual Life Outcomes. 2014;12:136.

26. Max-Exposito L, Amador-Campos JA, GomezBenito J, Lalucat-Jo L. Research Group on Severe Mental Disorder. The World Health Organization Quality of Life Scale Brief Version: a validation study in patients with schizophrenia. Qual Life Res. 2011;20:1079-89.

27. Morgan MY, Landron F, Lehert P. New European Alcoholism Treatment Study Group. Improvement in quality of life after treatment for alcohol dependence with acamprosate and psychosocial support. Alcohol Clin Exp Res. 2004;28:64-77.

28. Lahmek P, Berlin I, Michel L, Berghout C, Meunier N, Aubin HJ. Determinants of improvement in quality of life of alcohol-dependent patients during an inpatient withdrawal programme. Int J Med Sci. 2009;6:160-7.

29. Peters TJ, Millward M, Foster J. Quality of life in alcohol misuse: comparison of men and women. Arch Womens Ment Health. 2003;6:239-43.

30. LoCastro JS, Youngblood M, Cisler RA, Mattson ME, Zweben A, Anton RF, et al. Alcohol treatment effects on secondary nondrinking outcomes and quality of life: the COMBINE study. J Stud Alcohol Drugs. 2009;70:186-96.

31. Romeis JC, Waterman B, Scherrer JF, Goldberg J, Eisen SA, Heath AC, et al. The impact of sociodemographics, comorbidity and symptom recency on health-related quality of life in alcoholics. J Stud Alcohol. 1999;60:653-62.

32. Collins SE. Associations between socioeconomic factors and alcohol outcomes. Alcohol Res. 2016;38:83-94. 


\section{Važnost procjenjivanja kvalitete života u ovisnika o alkoholu}

Sažetak - Ovisnost o alkoholu ima jaki utjecaj na kvalitetu života i procjena kvalitete života se smatra validnom mjerom u procjeni uspješnosti tretmana osoba ovisnih o alkoholu. Cilj istraživanja je bio istražiti kvalitetu života i neke sociodemografske karakteristike osoba ovisnih o alkoholu u odnosu na zdrave osobe. Krossekcijsko istraživanje (koje je dio većeg istraživanja) uključilo je 207 osoba ovisnih o alkoholu i 329 zdravih osoba oba spola. Korišten je strukturirani intervju za sociodemografske i alkohološke podatke, hrvatska verzija 5.00. Mini internacionalnog neuropsihijatrijskog intervjua (MINI) i kratka verzija Upitnika o kvaliteti života Svjetske zdravstvene organizacije (WHOQoL-BREF). Rezultati su pokazali da su osobe ovisne o alkoholu bile značajno češće neobrazovane $(p=0,006)$ i primarnog obrazovanja $(p<0,001)$, dok su zdrave osobe bile značajno češće sekundarnog $(p=0,003)$ i tercijarnog obrazovanja $(p=0,013)$. Alkoholičari su bili značajno češće samci $(p=0,005)$, rastavljeni $(p<0,001)$ i žive u izvanbračnoj zajednici $(p=0,008)$ u odnosu na zdrave osobe, dok je zdrava populacija bila češće oženjena/udana $(p<0,001)$ u odnosu na osobe ovisne o alkoholu. Osobe ovisne o alkoholu su bile češće nezaposlene $(p<0,001)$ i umirovljene $(p=0,005)$. Osobe ovisne o alkoholu češće su imale percepciju osjećaja bolesti $(p<0,001)$ u odnosu na zdrave osobe. Postojale su značajne razlike u svim domenama kvalitete života: općoj, fizičkoj, psihološkoj, socijalnoj i okruženju između osoba ovisnih o alkoholu i zdravih osoba $(p<0,001)$. Zaključno, alkoholna ovisnost se pokazala negativno povezana s općom kvalitetom života i domenama kvalitete života: fizičkom, psihološkom, socijalnom i okruženjem. Obrazovanje osoba ovisnih o alkoholu je bilo niže u odnosu na zdrave osobe, koji su češće živjeli u braku i bili su zaposleni.

Ključne riječi: ovisnost o alkoholu, kvaliteta života, procjena 
